\title{
EFFECT OF MULCHING ON BANANA WEEVIL MOVEMENT RELATIVE TO PHEROMONE TRAPS
}

\author{
W. TINZAARA ${ }^{1,2}$, C. S. GOLD ${ }^{2,4}$, M. DICKE ${ }^{3}$, A. VAN HUIS ${ }^{3}$ and P.E. RAGAMA VA, $^{2,4}$ \\ ${ }^{1}$ Bioversity International, Uganda, P.O. Box 24384, Kampala, Uganda \\ ${ }^{2}$ National Banana Research Programme, Kawanda Agricultural Research Institute, \\ P.O. Box 7065, Kampala, Uganda \\ ${ }^{3}$ Laboratory of Entomology, Wageningen University, P.O. Box 8031, 6700 EH Wageningen, The Netherlands \\ ${ }^{4}$ International Institute of Tropical Agriculture, Eastern and Southern Africa Regional Centre,
} P. O. Box 7878, Kampala, Uganda

\begin{abstract}
Banana weevil (Cosmopolites sordidus) is a major pest in East Africa causing yield losses of up to 14 metric tonnes per hectare annually. A study was conducted in Uganda to determine the effect of mulching on banana (Musa spp. L.) weevil, Cosmopolites sordidus (Germar) (Coleoptera: Curculionidae), movement relative to pheromone-baited traps. Three treatments were used to create different mulching levels: banana without mulch (control), banana with thin mulch ( $<6 \mathrm{~cm}$ thick), and banana with thick mulch (15 cm thick). Pheromone traps were placed in the plots and weevil trap catches were monitored. Weevil catches in pheromone traps from both mulched and unmulched plots were generally similar. The mulching level had no effect on the ratio of males to females recaptured. The numbers of weevils captured in pheromone traps were lower than in the wet season and was not influenced by mulch levels. Mulching levels had a limited influence on the numbers of weevils recaptured from different directions. The results generally indicate that mulching has no effect on weevil catches in pheromone traps.
\end{abstract}

Key Words: Cosmopolites sordidus, Musa spp., season, Uganda

\section{RÉSUMÉ}

Le charançon de banane (les Cosmopolites sordidus) est une peste majeure dans l'Afrique de l'Est causant les pertes de rendement annuel de jusqu'à 14 tonnes par l'hectare. Une étude a été dirigée en Ouganda pour déterminer l'effet de paille sur la banane (Musa spp. L.) le charançon, les Cosmopolites sordidus (Germar) (Coleoptera : Curculionidae), le mouvement relatif aux pièges de phéromone-appâté. Trois traitements ont été utilisés pour créer différent niveaux des mulching : La banane sans le paillis (le contrôle), la banane avec le paillis mince ( $<6 \mathrm{~cm}$ épais), et la banane avec le paillis épais (15 cm épais). Les pièges de phéromone ont été placés dans les terrains et les prises de piège de charançon ont été contrôlées. Le charançon prend dans les pièges de terrains paillés et non paillé étaient généralement similaires. Le niveau de mulching n’a pas eu des effets sur le ratio des males et femmelles capturés. Les nombres de charançons capturé dans les pièges de étaient plus bas que dans la saison mouillée et n'était pas influencé par les niveaux de paillis. Niveaux de mulching a eu une influence limitée sur les nombres de charançons capturés dans différentes directions. Généralement les résultats indiquent que mulching n'a pas d'effet sur les prises de charançon dans les pièges.

Mots Clés: Les cosmopolites sordidus, Musa spp., la saison, Ouganda

\section{INTRODUCTION}

Banana weevil, Cosmopolites sordidus (Germar) (Coleoptera: Curculionidae), is a major pest in
East Africa. Weevil larvae cause damage by boring in the corm which results in reduced nutrient uptake of the plant. The adult's biology is characterised by nocturnal activity, 
hydrotropism, long life span (up to four years), low fecundity and limited mobility (Gold et al., 2001). The insect rarely flies and moves only short distances. The weevil tends to be more active in moist conditions and to move further in mulched than unmulched systems (Gold et al., 1999). Mulched systems often support larger populations than unmulched systems (Price, 1993; Rukazambunga et al., 2002).

Mulching has been a widely recommended practice to farmers in Uganda as a means of conserving moisture and reducing soil erosion in banana plantations. For example, Rukazambuga et al. (2002) found a yield increase in mulched farms. Yield loss to banana weevil was $14 \mathrm{t} \mathrm{ha}^{-1}$ in mulched systems compared to $8 \mathrm{t} \mathrm{ha}^{-1}$ where mulch was not applied (Rukazambuga et al., 2002).

The use of the banana weevil aggregation pheromone Cosmolure+ is currently being studied in Uganda for the control of $C$. sordidus, and results of laboratory and field experiments are promising (Tinzaara et al., 2000, 2003). The pheromone trap efficiency is influenced by cropping system (including mulching) and the biology of the insect (Hebblethwaite, 1989). Mulching influences weevil movements in banana plantations (Gold et al., 1999), but to what extent this would affect pheromone trap catches of $C$. sordidus is not known.

Mulching may have several effects on efficacy of pheromone lures in attracting $C$. sordidus. First, the mulch may impede dissemination of the pheromone through the field, as well as the weevil's ability to detect the pheromone. Secondly, weevils tend to be more active and move further in mulched fields presumably due to differences in soil moisture. Such activity may make weevils more responsive to the lures, as well as increase the likelihood of the weevils coming into contact with it.

The objectives of this study were to determine: (i) the effect of mulching on the number of weevils captured in pheromone-baited traps; (ii) distances moved by weevils relative to the pheromone-baited traps in mulched and unmulched plots; and (iii) the effect of direction from the pheromone-baited trap on weevil catches in mulched and unmulched plots.

\section{MATERIALSAND METHODS}

Site description. The experiment was conducted in the field at the IITA Sendusu Farm ( $0^{\circ} 32^{\prime} \mathrm{N}$, 32 ${ }^{\circ} 35^{\prime} \mathrm{E}, 1260$ metres above sea level), located 25 $\mathrm{km}$ north east of Kampala, Uganda. The site has two rainy seasons (March-May and SeptemberNovember) with mean annual rainfall of 1200-1250 mm and daily mean temperature of $21^{\circ} \mathrm{C}$.

Experimental design. The experiments consisted of three treatments: (i) banana without mulch (control); (ii) banana with thin mulch ( $<6 \mathrm{~cm}$ thick); and (iii) banana with thick mulch. Plots of 306.3 $\mathrm{m}^{2}$ with 7 rows of 7 banana mats each (Musa spp.) planted in a $2.5 \mathrm{~m}$ x $2.5 \mathrm{~m}$ arrangement were used. Plots were separated by $5 \mathrm{~m}$ alleys. The treatments were placed in a Randomised complete Block Design with three replicates. Cultivar Kibuzi, AAA-EA type was the experimental crop.

Field history, planting and management. The experimental field was previously planted with banana cultivar Atwalira (Musa spp, AAA-EA type), which was wiped out by weevil infestation. Two months before planting, the field was sprayed with Chlorpyrifos (dursban) to clean the field of weevil infestation before ploughing. The field was planted in October 2002. The planting material was obtained from farmers' fields in Masaka District, Uganda. Before planting, the pseudostems were cut $15 \mathrm{~cm}$ above the collar. The suckers were pared (cleaned by chopping off roots and the outer layer of the corm) and those showing weevil damage were discarded. The selected suckers were immersed in a solution of Chlorpyrifos ( $1.5 \mathrm{ml}$ per litre of water) for 30 minutes for further cleaning from banana weevil and nematodes (Tinzaara et al., 2002). Suckers were placed $10 \mathrm{~cm}$ below the soil surface in planting holes (60 cm diameter and $60 \mathrm{~cm}$ deep) containing soil and $20 \mathrm{~kg}$ of cow dung manure. Gap filling was done in December 2002. Plant density was maintained at three plants per mat. Weeds were controlled by spraying with Roundup (glyphosate) every 2-3 months at 300ml per 15 litres of water. Desuckering and detrashing were conducted when needed. 
Grass mulches (mixtures of Panicum maximum, Imperata cylindrica and Bracharia spp.) were first applied when the crop started to flower (May 2003). Approximately $150 \mathrm{~kg}$ of mulch were applied in the treatment for the thick mulch and $75 \mathrm{~kg}$ per plot for the thin mulch. Supplementary mulching was done every four months using the mulch material in the ratio of 5:2:0 for thick, thin and no mulch, respectively. The mulch was approximately $15 \mathrm{~cm}$ and $<6 \mathrm{~cm}$ thick for the thick and thin mulch, respectively.

Cosmopolites sordidus release. Adult weevils were collected from farmers' fields in Masaka District in Uganda using pseudostem traps (Mitchell, 1978). Weevil sex was determined using curvature of the last abdominal segment (Roth and Willis, 1963) and punctuation on the rostrum (Longoria, 1968). Before release, weevils were scratched on the elytra with distinct marks for each banana mat. Ten weevils ( 5 females and 5 males) were released in the evening (7.00-8.00 pm) at the base of the mats in each plot by placing them in shallow holes around the base. In each treatment, a total of 490 marked weevils ( 245 males and 245 females) was released per plot, one week before a pheromone-baited trap was placed in the centre of each plot. The distance of mats from the pheromone trap was recorded.

Pheromone trap placement. Pheromone was placed in each plot in the pitfall traps. A pitfall trap was prepared out of a 10-litre bucket following Tinzaara et al.'s (2000) procedure. The trap was placed at the base of the banana mat at the centre of the plot, one week after releasing the weevils. The pheromone lure (Cosmolure+) was hang from the top of the bucket. One trap per plot was placed at the central mat. Traps were checked every three days to make sure that they flushed well with soil level. A liquid detergent solution (1 litre) was placed in the trap as a trapping agent and was changed every five days. Pheromone traps were first placed during the wet season in August-October 2003 (trial 1). The experiment was repeated in the dry season between December 2003 and February 2004 (trial 2). Between trials, pseudostem traps (Mitchel, 1978) were placed on each of the banana mats in the plot once per week to remove weevils and reduce existing populations.

Sampling and data collection. Pheromone traps were checked every three days for 60 and 66 days for trials 1 and 2, respectively. Recaptured weevils were recorded, placed in vials and taken to the laboratory for differentiation according to their sex and mat of release.

As for the distance moved by weevil's relative to the traps, the number of weevils recaptured in pheromone traps within 18 days of trap placement was used to determine weevil movement relative to the pheromone trap in plots of different mulch levels. The number of weevils recaptured in pheromone traps was recorded according to the mat of release. To calculate distances moved by weevils, each banana mat in the plot was allotted co-ordinates. Data on weevil captures were grouped before analysis according to distance ranges moved relative to the trap.

The direction of banana mats relative to the pheromone traps on which weevils were released was recorded. The direction from where the weevils came was determined only for the weevils found in pheromone traps in the first 18 days of trap placement. The data were then grouped into direction quarters represented as East (SE-NE), North (NE-NW), West (NW-SW) and South (SW$\mathrm{SE}$ ) for analysis.

Data analysis. The weekly number of weevils captured from plots of different mulch levels was log transformed and analysed using ANOVA of SAS (1990). The means were separated using a Student-Newman-Keuls (SNK) test. The association of weevil trap catches with direction, distances moved in the different mulch levels was analysed using a contingency table test on numbers, followed by Bonferroni correction, $\mathrm{a}=$ $0.05 / 3=0.017$, for multiple comparisons for those that showed significant differences.

\section{RESULTS}

Pheromone trap catches and sex ratio of weevils. There were significantly more weevils (marked and unmarked) captured in pheromone-baited traps in thick mulch plots than from thin and no 
mulch plots in the first week of the first trial $(\mathrm{P}<0.05$, SNK test) (Fig. 1). In all subsequent sampling weeks, the catches were similar among treatments $(\mathrm{P}>0.05)$. There was a decline in weevil catches with time for all mulch levels. The total number of marked weevils that were recaptured from thick mulch and thin mulch plots was significantly $(\mathrm{P}=0.0001)$ higher than from unmulched plots (Table 1). More females were captured in mulched plots than in control plots $(\mathrm{P}=0.0001)$, while for males, the numbers recaptured between treatments were similar $(\mathrm{P}=0.48)$.
During the second Trial, weevil catches were similar for the three mulching levels ( $\mathrm{P}>0.05$ ), in all sampling weeks, except in the seventh week when the catches were higher from no mulch plots compared to thin mulch plots $(\mathrm{P}<0.05)$ (Fig. 1). There were no differences in total numbers of weevils recaptured from plots of different mulch levels $(\mathrm{P}=0.31)$ (Table 1$)$. The number of males $(\mathrm{P}=0.93)$ and females $(\mathrm{P}=0.26)$ recaptured from the different mulch levels were similar.

The numbers of weevils captured in pheromone traps were higher in Trial 1 than in the Trial 2 for thick $(\mathrm{P}<0.001)$, thin $(\mathrm{P}<0.0001)$

Trial 1

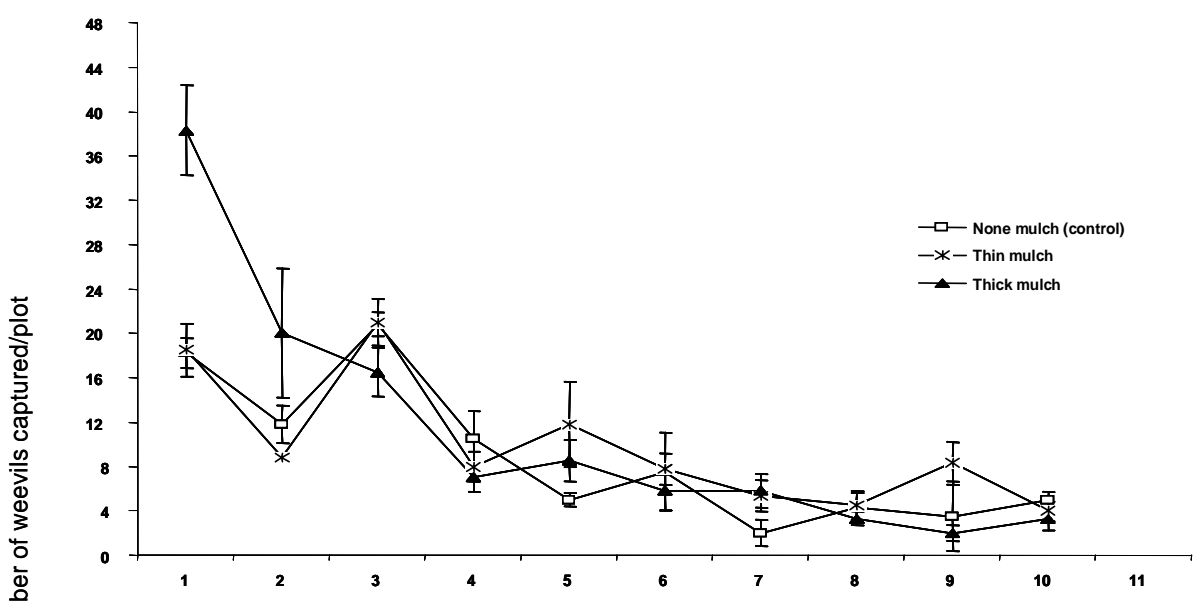

Trial 2

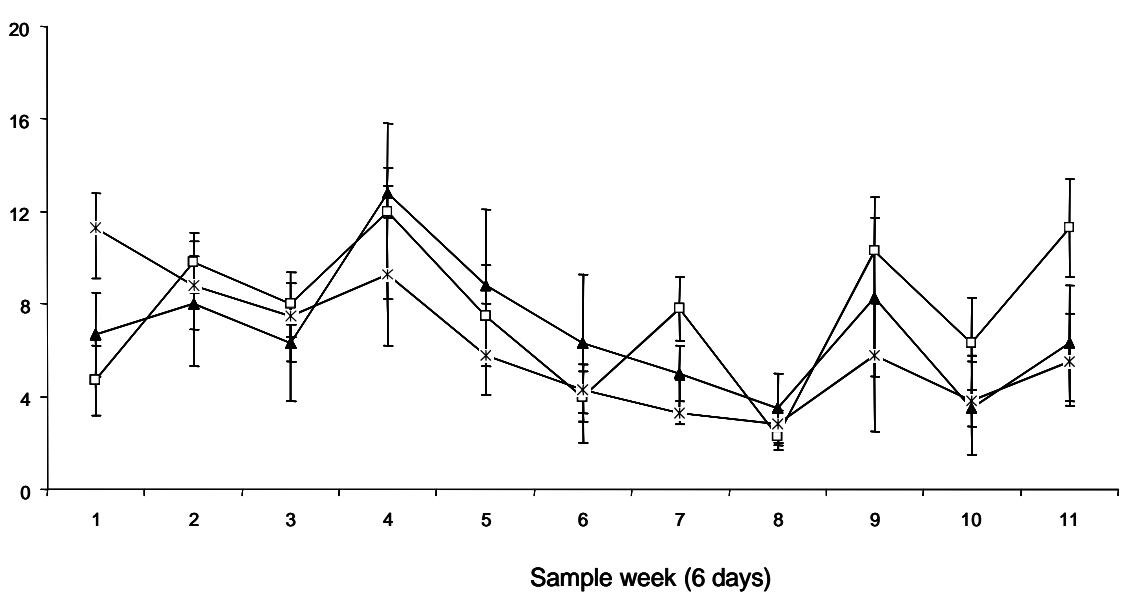

Figure 1. Number of banana weevils captured in pheromone-baited traps in mulched and unmulched plots during the wet (Trial 1) and the dry season (Trial 2). 
and no mulch levels $(\mathrm{P}=0.003)$ (Table 1$)$. The ratio of males to females recaptured in both trials for each of the mulch levels was similar. In all instances more females than males were recaptured $(\mathrm{P}<0.05$, $2 \mathrm{x} 2$ contingency table test).

Distance moved by weevils relative to the pheromone trap. Of the weevils released at distances of 3.1- $6.0 \mathrm{~m}$ and 6.1-9.0 $\mathrm{m}$ from the pheromone-baited trap, more individuals were recaptured in the thick mulch than in the no-mulch treatment during the wet season (Trial 1) (Table
2 ). The number of weevils recaptured from other distances from the trap was similar for the different mulch treatments. During the dry season, the recapture of weevils per release distance were similar between mulch levels (Table 2). The number of weevils recaptured per release distance was higher in the wet season than in the dry season.

Effect of direction on trap catches. During the wet season, the numbers of weevils that were recaptured in pheromone traps from the south

TABLE 1. Number and sex ratio of weevils attracted to pheromone-baited traps in plots of different mulching levels (after 60 and 66 days for trial 1 and 2, respectively) at Sendusu, Uganda

\begin{tabular}{|c|c|c|c|c|c|c|}
\hline \multirow[t]{2}{*}{ Trial } & \multirow[t]{2}{*}{ Mulch layer } & \multicolumn{4}{|c|}{ Number of weevils captured } & \multirow[t]{2}{*}{ Male: females ${ }^{2}$} \\
\hline & & Males $^{1}$ & Females ${ }^{1}$ & Unmarked & Total recaptured ${ }^{1}$ & \\
\hline \multirow[t]{3}{*}{1} & Thick & 67 & $158 \mathrm{a}$ & 209 & $225 a$ & $1: 2.4$ \\
\hline & Thin & 61 & $143 a$ & 184 & $204 a$ & $1: 2.4$ \\
\hline & None (control) & 54 & $94 b$ & 167 & $148 \mathrm{~b}$ & $1: 1.7$ \\
\hline \multirow[t]{3}{*}{2} & Thick & 17 & $67 a$ & 148 & $84 a$ & $1: 3.9$ \\
\hline & Thin & 19 & $66 \mathrm{a}$ & 121 & $85 a$ & $1: 3.4$ \\
\hline & None (control) & 19 & $83 a$ & 126 & $102 a$ & $1: 4.4$ \\
\hline
\end{tabular}

${ }^{1}$ Numbers in a column, per trial, followed by the same letter are not significantly different (contingency table test followed with Bonferroni correction of $a=0.05 / 3=0.017$ for multiple comparisons)

${ }^{2}$ The ratio of males to females recaptured was significantly different from 1:1 in all mulch levels ( $P<0.05$, contingency table test)

TABLE 2. Number of weevils recaptured in pheromone-baited traps after release at different distances from the traps in mulched and unmulched plots during the first 18 days of trap placement

\begin{tabular}{|c|c|c|c|c|c|c|}
\hline \multirow[t]{2}{*}{ Trial } & \multirow{2}{*}{$\begin{array}{c}\text { Release } \\
\text { distance from } \\
\text { pheromone } \\
\text { trap }(\mathrm{m})\end{array}$} & \multirow[t]{2}{*}{ Weevils released } & \multicolumn{3}{|c|}{ Number of weevils recaptured from a distance } & \multirow{2}{*}{$\begin{array}{c}\mathrm{P} \text { (Contingency } \\
\text { table test) }\end{array}$} \\
\hline & & & Thick mulch & Thin mulch & No mulch & \\
\hline \multirow[t]{4}{*}{1} & $0.0-3.0$ & 200 & 32 & 18 & 24 & 0.1 \\
\hline & $3.1-6.0$ & 640 & $62 a$ & $39 a b$ & $38 b$ & 0.014 \\
\hline & $6.1-9.0$ & 960 & $64 a$ & $41 a b$ & $38 b$ & 0.011 \\
\hline & $9.1-12.0$ & 160 & 9 & 8 & 2 & 0.094 \\
\hline \multirow[t]{4}{*}{2} & $0.0-3.0$ & 200 & 8 & 2 & 4 & 0.13 \\
\hline & $3.1-6.0$ & 640 & 14 & 17 & 24 & 0.22 \\
\hline & $6.1-9.0$ & 960 & 15 & 14 & 14 & 0.98 \\
\hline & $9.1-12.0$ & 160 & 1 & 6 & 2 & 0.09 \\
\hline
\end{tabular}

Numbers in a row that are followed by the same letter are not significantly different (contingency table test followed with Bonferroni correction of $a=0.05 / 3=0.017$ for multiple comparisons) 
and east directions from the trap were larger than those that were recaptured from north and west directions in all mulch levels (Table 3). More weevils were recovered in thick mulch than in the no mulch plots for the eastern western directions. The numbers of weevils recovered from mulched and unmulched plots were similar for the southern and northern directions. During the dry season, the numbers of weevils recaptured in mulched and unmulched plots were similar for southern, eastern and western directions (Table 3), but for the northern direction more weevils were recovered from thick mulch than no mulch plots.

\section{DISCUSSION}

In the present study, weekly pheromone trap catches from mulched and unmulched plots were generally similar. However, the total numbers of weevils recaptured in pheromone-baited traps in mulched plots were higher in thick-mulched than unmulched plots in the wet season. Nevertheless, catches were similar in the dry season. The data did not agree with our hypothesis that mulching may affect trap catches. The higher recapture in thick mulch plots during the wet season could be related to the higher weevil activity and movement during the wet conditions. Weevils are active in wet/moist conditions and become sedentary during dry conditions (Gold et al., 1999); and their ability to detect pheromones may be decreased.

Equal numbers of males and females were released in our trials. In both mulched and unmulched plots, more females than males were recaptured. Similarly, Delattre (1980) caught more female weevils than males in pseudostem traps in the field during the rainy season when moisture was high. Mulching did not affect the sex ratio of the captured weevils. Female weevils may move more and may have greater activity than males as they search for oviposition sites and mates. Indeed, it has been reported that female weevils are more attracted by the male produced aggregation pheromones than males (Budenburg et al., 1993; Tinzaara et al., 2005).

Weevils are reported to be more active and move longer distances in mulched than unmulched areas (Gold et al., 1999).

The results indicate that more weevils were captured from thick mulch than in the no mulch plots only in the distance ranges of three to nine metres during a wet season. In the dry season, there was no effect of distance on the weevil catch. Therefore, the effect of mulch level on the distance the weevil covered towards the pheromone traps was not substantial. The results do not support the hypothesis that during the

TABLE 3. Percentage of weevils recaptured from different directions relative to the pheromone trap in plots with different mulching levels

\begin{tabular}{|c|c|c|c|c|c|}
\hline \multirow[t]{2}{*}{ Trial } & \multirow{2}{*}{$\begin{array}{l}\text { Direction of weevil } \\
\text { recaptured }\end{array}$} & \multicolumn{3}{|c|}{ Weevils recaptured (\%) } & \multirow{2}{*}{$\begin{array}{c}\mathrm{P} \text { (Contingency } \\
\text { table test) }\end{array}$} \\
\hline & & Thick mulch & Thin mulch & No mulch & \\
\hline \multirow[t]{5}{*}{1} & Pheromone trap mat & 25.0 & 20.0 & 17.5 & 0.70 \\
\hline & South & 14.2 & 11.9 & 9.8 & 0.11 \\
\hline & East & $12.5 a$ & $9.4 a b$ & $7.0 \mathrm{~b}$ & 0.017 \\
\hline & North & 7.9 & 4.2 & 5.2 & 0.036 \\
\hline & West & $7.9 a$ & $6.0 a b$ & $3.5 b$ & 0.015 \\
\hline \multirow[t]{5}{*}{2} & Pheromone trap mat & 2.5 & 5.0 & 5.0 & 0.81 \\
\hline & South & 3.3 & 3.1 & 9.0 & 0.04 \\
\hline & East & 6.0 & 6.3 & 5.4 & 0.85 \\
\hline & North & $2.9 \mathrm{~b}$ & $5.4 a b$ & $8.8 \mathrm{a}$ & 0.0003 \\
\hline & West & 5.0 & 2.5 & 4.6 & 0.11 \\
\hline
\end{tabular}

Direction quarters represent East (SE -NE), North (NE-NW), West (NW-SW) and South (SW-SE). Numbers in a row followed by similar letters are not significantly different (contingency table test analysis on numbers followed with Bonferroni correction of a $=0.05 / 3=0.017$ for comparisons) 
wet season, the pheromone may adsorb to mulch leading to reduced catches in the traps. The numbers of weevils captured in pheromone traps from different distances in the dry season were lower than in the wet season and not influenced by mulch levels. This implies that weevils are less active during the dry season. Weevils become sedentary in the dry season and chances of coming in contact with the pheromone lures are low.

There was a limited effect of mulch level on the direction from which weevils were recaptured relative to the pheromone-baited traps. Weevil movement from a given direction relative to the pheromone trap has an association with the wind direction (Howse et al., 1998). The results of our study however showed that wind direction did not substantially influence trap catches. Our recent studies also showed that wind speed was reported to have a limited effect on weevil catches in pheromone baited traps (Tinzaara et al. 2005). Moreover, wind speed at the ground level in banana plantations is expected to be low.

The proportion of adult $C$. sordidus recaptured in pheromone traps in the different mulch levels was $7-11 \%$ in the wet and $4-5 \%$ in the dry season. The level of field sanitation and environmental factors were found to contribute to the low pheromone trap catches in our banana cropping system (Tinzaara et al., 2005). Trap catches are also likely to be influenced by pheromone efficacy. However, since the pheromone traps in this study were not very effective in recapturing high numbers of weevils (Tinzaara et al., 2005), the effect of mulching on trap catches may have been underestimated.

The results of this study generally indicate that mulch levels do not have a substantial effect on weevil catches in pheromone-baited traps. Furthermore, the different mulch levels have no effect on the sex ratio of weevils captured. Also, mulch level has no substantial effect on the distances moved by weevils towards the pheromone-baited traps. Although the number of weevils caught in pheromone traps in the dry season was numerically lower, no effect of mulching was observed on trap catches. Mulching, therefore, is compatible with use of pheromone traps.

\section{ACKNOWLEDGEMENTS}

We acknowledge financial support from Wageningen University Ph.D. Sandwich Fellowship and the Rockefeller Foundation through a grant to International Institute of Tropical Agriculture. We are grateful to Dr. A.C. Oehlschlager of Chemtica International, Costa Rica, for providing pheromone lures used in the study. Dr. W. Tushemereirwe of National Banana Research Programme is acknowledged for support. Mukasa, D. and F. Sebulime assisted in data collection.

\section{REFERENCES}

Budenberg, W.J., Ndiege, I.O. and Karago, F.W. 1993. Evidence for volatile male-produced pheromone in Banana Weevil Cosmopolites sordidus. Journal Chemical Ecology 19: 1905-1916.

Delattre, P. 1980. Recherche d'une methode d'estimation des populations du charancon du bananier, Cosmopolites sordidus Germar (Col., Curculionidae). Acta Oecologica: Oecologia Applicata 1:83-92.

Gold, C.S., Rukazambuga, N.D.T.R., Karamura, E.B., Nemeye, P. and Night, G. 1999. Recent Advances in Banana Weevil Biology, Population Dynamics and Pest Status with Emphasis on East Africa. In: Frison, E., Gold, C.S., Karamura, E.B. and Sikora, R.A. (Eds.), pp. 35-50. Mobilizing IPM for sustainable banana production in Africa. Proceedings of a Workshop on Banana IPM held in Nelspruit, South Africa, 23-28 November 1998. INIBAP. Montpellier.

Gold, C.S., Pena, J.E. and Karamura, E. B. 2001. Biology and integrated pest management for the banana weevil, Cosmopolites sordidus (Germar) (Coleoptera: Curculionidae). Integrated Pest Management Reviews 6: 79155.

Hebblethwaite, M. 1989. Adoption of Pheromones in Pest Control. In: Jutsum, A.R. and Gordon, R.F.S. (Eds.), pp. 303-322. Insect pheromones in plant protection. John Wiley and Sons, New York. 
W. TINZAARA et al.

Howse, P., Stevens, I. and Jones, O. 1998. Insect pheromones and their use in pest management. Chapman and Hall, London, UK. pp. 105-130.

Longoria, A. 1968. Diferencias sexuales en la morfologia externa de Cosmopolites sordidus Germar (Coleoptera, Curculionidae). Ciencias Biol, La Habana 1: 1-11.

Mitchell, G.A. 1978. The estimation of banana borer population and resistance levels. WINBAN Research and development Technical bulletin No. 2. pp. 34.

Price, N.S. 1993. Preliminary weevil trapping studies in Cameroon. In: Gold, C.S and Gemmill, B. (Eds.), pp. 57-67. Biological and Integrated Control of Highland Banana and Plantain Pests and Diseases. Proceedings of a Research Coordination Meeting. Cotonou, Benin. International Institute of Tropical Agriculture.

Roth, L. and Willis, E. 1963. The humidity behaviour of Cosmopolites sordidus (Germar) (Coleoptera:Curculionidae). Annual Entomological Society of America 56:41-42.

Rukazambuga, N.D.T.M., Gold, C.S. and Gowen, S.R. 2002. The influence of crop management on banana weevil, Cosmopolites sordidus (Coleoptera: Curculionidae) populations and yield of highland cooking banana (cV Atwalira) in Uganda. Bulletin of Entomological Research 92:413-421.
SAS. 1990. SAS Institute Inc., SAS/STAT Users' Guide Version 6, Fourth Edition, V.II.

Tinzaara, W., Dicke, M., Van Huis, A., Van Loon, J.J.A and Gold, C.S. 2003. Different bioassays for investigating orientation responses of the banana weevil, Cosmopolites sordidus (Germar) show additive effects of host plant volatiles and the synthetic pheromone. Entomologia Experimentalis et Applicata 106: 169-175.

Tinzaara, W., Kashaija, I., Tushemereirwe, W. and Nankinga, C. 2002. Comparative studies on chemical, hot water and cold water treatments of banana suckers to control the banana weevil, Cosmopolites sordidus Germar and the effect of paring suckers on banana nematodes in Uganda. Uganda Journal of Agricultural Sciences 7: 43-47.

Tinzaara, W., Gold, C.S., Dicke, M., van Huis, A. and Ragama, P.E. 2005. Factors influencing pheromone trap effectiveness in attracting the banana weevil, Cosmopolites sordidus. International Journal of Pest Management 51: 281-288.

Tinzaara, W., Tushemereirwe, W. and Kashaija, I. 2000. Efficiency of pheromones and trap types in the capture of the banana weevil Cosmopolites sordidus Germar in Uganda. Uganda Journal of Agricultural Sciences 5: 91-97. 